\title{
Research on the Development Practice of Chinese Coastal Homestay Houses and Its Countermeasures*
}

\author{
Mo Chen \\ School of Humanities \\ Zhejiang Ocean University \\ Zhoushan, China
}

\begin{abstract}
Taking the homestay houses in Zhoushan, Zhengjiang Province, China as an example, analyze the feasibility of rebuilding coastal homestay houses with deductive logic and example argumentation and other analytical methods from the situation of Chinese oceanic tourism resources to the activation situation and development of coastal villages and homestay houses, advantages and disadvantages, pattern analysis and countermeasure research of activating homestay houses. Meanwhile, discuss the follow-up popularization after rebuilding homestay houses through analysis and research on Internet Plus.
\end{abstract}

Keywords-coastal homestay houses; activation; Zhoushan; resident house design

\section{INTRODUCTION}

With the impetus of economic development, people's living standards continue to improve. Meanwhile, the tourism market is flourishing. Ecotourism has become popular at present, so the resident house tourism is developed gradually across the country as a new tourist industry, such as the coastal homestay houses in the tourist industry of Zhoushan, which has played a more and more important role. Therefore, it is a new stage in which opportunities and challenges coexist.

Research and analyze the practice of resident house construction with zero cost referring to ecological coast, and discuss the role played by the original ecology idea in the construction of coastal homestay houses with the coastal villages in Zhoushan Archipelago New Area as an example in order to improve the ecological protection and activation of coastal villages.

\section{Situation Of ChINESE OcEANIC TOURISM Resources}

China is a Shipping power, fishing power, shipbuilding power and maritime power, which owns $18000 \mathrm{~km}$ of continental coastline and $14000 \mathrm{~km}$ of island coastline. 274 oceanic tourism resources have been discovered in China according to the preliminary statistics of the Classification, Investigation and Evaluation of Tourism Resources (GB/T18972-2003), most of which are distributed in Zhejiang, Liaoning, Jiangsu, Shandong and Guangdong.

*This article is one of the research results of the Zhejiang philosophy and social science project, "Research and Practice of Designing Homestay Houses with Zero Cost in the Background of Ecological Island Construction --- Take the Coastal Villages in Zhoushan Archipelago New Area as an Example" (No. 16NDJC223YB).
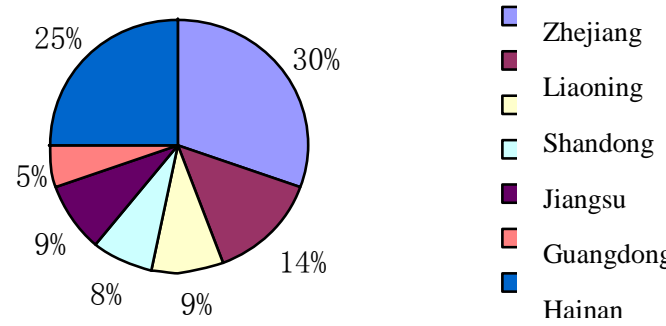

Fig. 1. Distribution of Chinese oceanic tourism resources

The oceanic tourism resources in Zhejiang account for $20 \%$ of total. If develop the coastal homestay houses to improve economic benefit with the advantageous coastal conditions and strong ocean culture background in Zhejiang, the development space is very big.

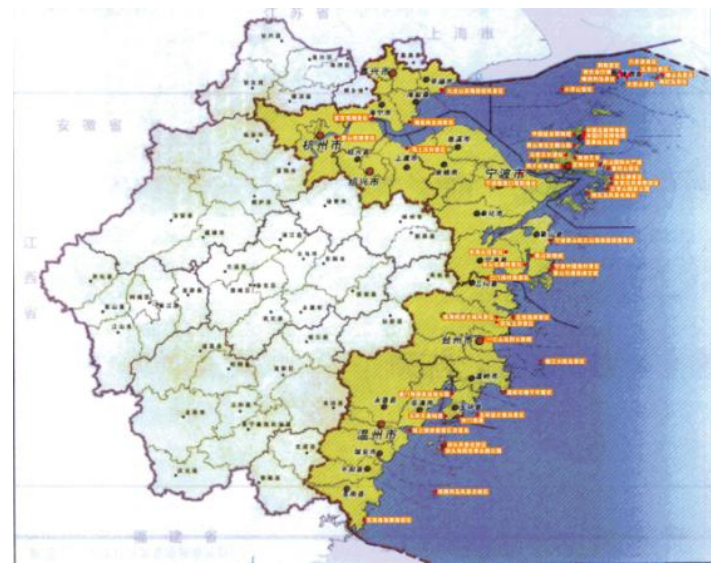

Fig. 2. Distribution map of typical oceanic tourism resources in Zhejiang

\section{ACTIVATION SitUATION AND DEVELOPMENT OF COASTAL VILLAGES AND HOMESTAY HOUSES}

Homestay houses are the unoccupied rooms of self-living houses provided by local people to tourists when they tour and experience the life in local place in the business mode of family sideline combined with local unique cultural and natural landscapes, ecological environment resources and life and 
production activities of farming, forestry, husbandry and fishing. In other words, homestay houses are the houses provided to tourists for experiencing coastal life, which are smaller than star hotels, but cozy. Just under this trend, the development of homestay houses is paid more and more attention. In this definition, it is emphasized that homestay houses are an industry with families as guiding. That is to say, family operation is a characteristic and element of homestay houses. [1]

The word "resident house" originated from some European and American capitalist countries, and then it was introduced into Asia. In Asia, Japanese coastal homestay houses have been developed with large scale, which is typical. In China, the homestay houses in Taiwan, Lijiang and other places were developed earlier and typically, and now an initial scale has been formed. To activate coastal villages and homestay houses needs industrialization development, which will not only make the coastal villages overcome poverty and achieve prosperity and develop, but also will provide conditions for all kinds of consumer groups for returning to nature, experiencing traditional culture, seeking childhood memories, teaching through lively activities and the harmony between human and nature. Therefore, the market potential is great.

In the development practice of coastal homestay houses, we should always pay attention to the coastal landscape features and the characteristics of marine folklore culture. During the construction process, we shall make full use of local original landscapes to always run the original ecology idea through the rebuilding and development of coastal homestay houses. Meanwhile, the ocean culture in Zhoushan has unique advantages for the development of coastal homestay houses. Therefore, during the practice process, we shall consider to maximize the marine culture elements with Zhoushan characteristics to blend in the rebuilding of coastal homestay houses, in order to enrich the regional features of tourism culture. [2]

The coastal homestay houses are being developed, and primitive homestay houses are being rebuilt prosperously. The advantageous conditions have being promoted the development of homestay houses in Zhoushan.

\section{AdVANTAGE AND DisadVANTAGES to ACTIVATE THE} COASTAL VILLAGES AND HOMESTAY HOUSES IN ZHOUSHAN

The homestay houses in Zhoushan City, China was started to develop in 1990s. Up to now, the development speed of coastal homestay houses has been accelerated. As a city having many islands, the coastal tourism resources in Zhoushan are a great advantage for local tourism development. Zhoushan always takes the marine economy as the principal line of economic development, so coastal homestay houses paid more and more attention as the carriers of tourism economic development.

Zhoushan explores the ocean culture deeply to expand the influence of coastal homestay houses with fishing experience, sea sports and other ocean resources. At present, there are about 100 boutique homestay houses increased every year. It is predicted that there will be 400 boutique coastal homestay houses in Zhoushan until to 2020. The tourism industry accounts for over $6 \%$ of total GDP in Zhoushan City, in which, coastal homestay houses make some contribution.

\section{A. Advantages}

\section{1) Geographical conditions}

Zhoushan Archipelago New Area composed of 1390 islands has the good names of Fish Storehouse in East Sea and China Fishing City, which has three advantages: fishing, ports and tourism industry for its economic development. Zhoushan has many islands, which account for $20 \%$ of total islands in China, so these numerous coastal resources are the specific advantage for the ocean tourism development of Zhoushan.

\section{2) Policy support}

With the construction of Zhoushan Archipelago New Area and the continuous advance of Zhoushan Archipelago Oceanic Tourism Pilot Region for Comprehensive Reforms, the tourism development of homestay houses shows a rising trend, and the introduction of relevant policies also promote the development of coastal homestay houses.

In 2011, Zhoushan City issued the Opinions on Promoting the Comprehensive Development of Recreational Tourism of Fishing and Agritainment, in which, relevant concrete measures, development objective and governmental supportive policies for the development of resident house industry were put forward, and the governments at all levels should appropriate special funds to primary-level coastal resident house associations as budget subsidy in order to support them to carry out various activities. In December 2015, the idea to develop roadhouses, homestay houses, short-term rental apartments, long-term rental apartments and other subdivided business types was proposed for the first time in the Guiding Opinions of General Office of the State Council on Accelerating Living Service Industry for Upgrading Consumption Structure. On February 17, 2016, the departments released the Guiding Opinions on Promoting Green Consumption jointly to encourage the effective use of personal idle resources and orderly development of leasing homestay houses. At local level, the concept of homestay houses was defined in the Regulations of Zhejiang Province on Administration of Tourism, which was the first time to implant the concept of homestay houses into the domestic laws and regulations and bring it into the affair procurement scope of government agencies and enterprises and public institutions.

\section{3) Practice power}

In recent years, the development of fishing entertainment in Zhoushan City has been effective since from the beginning, which lays a good foundation for the current development of homestay houses. For the problems, such as old-fashioned idea, low-end operation, bad industry image, featurelessness, and difficulty on improving quality, Jin Feizhen, a representative of Municipal People's Congress, put forward to establish operation idea of homestay houses and development pattern of homestay houses planned in whole region; the government should publish the Industrial Development Planning for Beautiful Coastal Homestay Houses to blend Buddhist culture, ocean culture and the superior resources of mountains and ocean in the development of homestay houses scientifically plan the regional pattern of difference development of homestay houses, and create an industry chain of homestay 
houses. Meanwhile, mix the development of homestay houses and the creation of characteristic villages together to make the beautiful coastal homestay houses distinctive in all landscapes and become a new tourism business type in Zhoushan. [3] Therefore, the correct idea is an important factor for the successful development of homestay houses.

According to the unique characteristics of ocean culture and local conditions in Zhoushan City, seek the new development of coastal homestay houses with the concept of original ecology in practice.

The development of coastal homestay houses in Zhoushan was effective obviously at the beginning because on the one hand, the government published a series of supportive policies; on the other hand, the local fishermen participated in it actively Meanwhile, the active participation, practice and research of colleges and universities helped local fishermen to rebuild the coastal homestay houses and provided them more innovative ideas so as to promote the rebuilding and development of coastal homestay houses in Zhoushan.

\section{B. Disadvantages}

At present, the development of coastal homestay houses in Zhoushan is still unsubstantial, so we still need to continue to explore further, accumulate experience in practice, and improve development in the research if we want to maximize the use of ocean resources effectively to become a powerful measure to protect ocean ecology, innovate ocean culture and promote the development of ocean tourism.

\section{1) Old-fashioned ideas and lack of innovation} consciousness

In the present state of economic development, the rapid development of urban economy causes that there are more and more empty-nest old people and leftover children in the rural areas and young people have poured into the city one after another, which is not conducive to regional economic development and cultural construction. This phenomenon is more obvious on some remote small islands of Zhoushan. In the villages of these islands, because of limit of traffic and other conditions, it is very difficult to communicate with the outside world, people's ideas are old-fashioned, and they lack innovation consciousness.

All these problems are not conducive to the development of homestay houses. On some small islands, there are many unique ocean folk cultures handed down after long term of historical accumulation. However, these folk cultures are only limited in their life ranges, and the people lack communication with the outside world, which will lead fishermen to cling to old-fashioned ideas and lack innovation consciousness.

At present, the general operation levels of coastal homestay houses are not high, fishermen's educational level is low, and they lack modern operation ideas and only pursue immediate economic interests. In addition, the market regulation mechanism is lacked, arbitrary price increase and unordered competition are pervasive, and the issues on extensive operation and non-benign circulation in medium and low-end market are obvious. [4] Meanwhile, the extensive development mode of ocean economy has deviated from the original intention of original ecology to a certain extent.
At present, the analysis on employment of coastal fishermen produced by questionnaire shows that the development of homestay houses accords with employment demand of current people, and is a reflection that Chinese people want to return to pastoral. "Table I"

TABLE I. ANALYSIS BALANCE SHEET ON EMPLOYMENT DECISION

\begin{tabular}{|c|c|c|c|c|}
\hline & $\begin{array}{c}\text { Weight } \\
(-5 \text { to } \\
5)\end{array}$ & $\begin{array}{c}\begin{array}{c}\text { Owners of } \\
\text { homestay } \\
\text { houses }\end{array} \\
\text { Gain (+) loss } \\
(-)\end{array}$ & $\begin{array}{c}\text { Enterprise } \\
\text { employees } \\
\text { Gain (+) } \\
\text { loss (-) }\end{array}$ & $\begin{array}{c}\text { Fishermen } \\
\text { Gain (+) } \\
\text { loss (-) }\end{array}$ \\
\hline \multicolumn{5}{|l|}{$\begin{array}{l}\text { Personal } \\
\text { material gains } \\
\text { and losses: }\end{array}$} \\
\hline 1. Income & 5 & 20 & 15 & 20 \\
\hline $\begin{array}{lr}2 . & \text { Work } \\
\text { environment }\end{array}$ & 4 & 16 & 16 & 12 \\
\hline $\begin{array}{l}\text { 3. Future } \\
\text { development }\end{array}$ & 5 & 25 & 20 & 15 \\
\hline $\begin{array}{l}\text { Material gains } \\
\text { and losses of } \\
\text { others: } \\
\text { 1. Household } \\
\text { income }\end{array}$ & 5 & 20 & 10 & 15 \\
\hline $\begin{array}{l}\text { 2. Family } \\
\text { status }\end{array}$ & 3 & 18 & 15 & 12 \\
\hline \multicolumn{5}{|l|}{$\begin{array}{l}\text { Personal } \\
\text { spiritual gains } \\
\text { and losses: }\end{array}$} \\
\hline 1. Social status & 4 & 20 & 16 & 8 \\
\hline $\begin{array}{l}2 . \quad \text { Suitable } \\
\text { personal } \\
\text { interests }\end{array}$ & 4 & 20 & 16 & 12 \\
\hline $\begin{array}{ll}\begin{array}{l}\text { 3. } \\
\text { effect }\end{array} & \text { Health } \\
\end{array}$ & 3 & 18 & 21 & 15 \\
\hline \multicolumn{5}{|l|}{$\begin{array}{l}\text { Spiritual gains } \\
\text { and losses of } \\
\text { others: }\end{array}$} \\
\hline 1. Parents & 5 & 20 & 15 & 10 \\
\hline 2. Friends & 4 & 16 & 12 & 8 \\
\hline Total scores & 42 & 193 & 156 & 127 \\
\hline
\end{tabular}

\section{2) Homogenization phenomenon}

With the gradual popularity of the idea of common development of environmental protection and economy proposed by general secretary, Xi Jinping, the development of homestay houses becomes hotter and hotter. Correspondingly, the homogenization phenomenon of homestay houses begins to appear repeatedly. Blind copy not only causes to lose ocean culture features for the development of coastal homestay houses without competitive advantages, but also causes the ocean folk culture to be ignored easily and the utilization rate of ocean resources not to be improved.

The coastal homestay houses in Zhoushan are mainly divided three types according to the investigation of related departments: the first type is the unique coastal homestay houses with certain design concepts and having local customs and practices and oceanic features, which are few at present but can play an exemplary role for reference; the second type is the refurbished coastal homestay houses on the basis of original houses, most of which are imitations and lack individual 
features, but have some ocean elements more or less with the idea of original ecology; the third type is coastal homestay houses decorated commonly without features, which lack design styles and less or no ocean elements and are common inland, so they have no advantage for ocean tourism.

Coastal homestay houses have single mode and lack the features of ocean culture. Therefore, both operation mode and theme design for them are homogenized. Meanwhile, the owners of homestay houses have low professional level and lack design consciousness, which causes the common practice of imitation.

\section{3) Poor infrastructure}

Compared to inland, the infrastructure construction in coastal villages is poor. Because of poor traffic and other conditions, the main life style of coastal fishermen is to adjust measures to local conditions and use local materials. The coastal homestay houses have unique oceanic features. Most materials of local houses are related to ocean, for example, the materials of walls and roofs are most original materials get from the seaside. Poor infrastructure restricts the rebuilding of coastal homestay houses. Meanwhile, in the tourism development of coastal homestay houses, the bearing capacity of the infrastructure in coastal villages obviously fall behind the capacity of tourist, and many environmental problems spring up, but corresponding equipment for remoulding infrastructure is not in place in time, all of which are unfavourable to the development of coastal homestay houses.

\section{4) Single mode}

In the tourism of coastal homestay houses in Zhoushan, the function of the homestay houses is only to provide the accommodation and catering service to tourists, and the nearby oceanic features are not used, so the travel mode of homestay houses is single and the corresponding industry chain is not formed. However, the phenomenon of single experience mode in the development of coastal homestay houses can be improved by the way of extending the industry chain.

For the problem of single development mode and less experience modes of coastal homestay houses, a travel mode that let tourists participate in the practice of rebuilding coastal homestay houses is feasible. Meanwhile, we can maximize the idea of original ecology to be known by more people and implant the idea into the practice, which will cater to the current theme of ecological civilization development and is helpful to the full utilization of ocean resources.

\section{5) Scattered development and lack of plans}

The main operation mode of homestay houses in Zhoushan is independent operation, and operators communicate with each other less in the industry. This operation mode is helpful to keep the different features of coastal homestay houses, but on the other hand, it is harmful to the industry communication and the integral development of the coastal homestay houses in Zhoushan. Therefore, it is difficult to develop the homestay houses with original ecology without a unified scale.

If the government issues some relevant policies to train the owners of homestay houses uniformly, not only they can receive the operation mode of original ecology better, but also the homestay houses can be planned uniformly to rebuild in order to promote the integral development of homestay houses in Zhoushan.

\section{6) Cultural lag}

Ecotype, coastal style, local style, and oceanic recreational style shall be the important development directions of the homestay houses in Zhoushan. In recent years, the development of homestay houses is homogenized with hotels more and more seriously. At present, many tourism projects are urbanized and built into pure scenic spots and real estate projects in the development idea, which are caused by relevant enterprises and departments which blindly deem urban planning and scenic spot planning as same as the tourism development planning, so that related industries lose competitiveness in the tourism market. [5] This phenomenon that follow urbanization blindly and fail to combine the rebuilding of coastal homestay houses with local ocean folk culture, on the on hand, causes the development of coastal homestay houses to lose the unique competitive edge with inland homestay houses; on the other hand, it is difficult to realize the rebuilding method of adjusting measures to local conditions and making the best use of everything with the development pattern of excessive urbanization.

\section{ANALYSIS OF THE ACTIVATION PATTERN OF COASTAL VILLAGES AND HOMESTAY HOUSES IN ZHOUSHAN}

The advantages and disadvantages influence the activation of coastal villages and homestay houses in Zhoushan. At present, the development of times is in the general background of internet. Internet can improve the current passive situation faced by the popularization of coastal homestay houses to a certain extent, and the internet pattern plays a crucial role in activating the coastal villages and homestay houses in Zhoushan, and it provides new thought, methods and means for its breadth, depth, safety, reliability, pertinence, universality and other aspects. Use new techniques to narrow the distance between the masses and the tradition, use new guiding patterns and establish new tourism mode so as to achieve the purpose of trans-boundary of tradition and internet to provide enough endogenetic force for rebuilding coastal resident houses with original ecology and zero cost.

\section{A. Broaden Popularization Channels with Different Techniques \\ 1) $U G C$ and $U G M$ \\ - UGC}

Users show their original contents through the internet platform (blogs, video sharing, community network and other application forms).

\section{- UGM}

According to the traces on the internet leaved by users, establish a market, provide relevant services, and breed a new market for whole internet at the same time. That is to say, to marketize users' contents and online behaviors is a new type of product form and marketing pattern participated by all people.

Thus we shall use UGC technique to gather the people having same interests to participate in the business they are interested in and organize them rapidly on the internet platform 
in order to speed up information spreading, change traditional tourism modes and play the role in development process of coastal homestay houses.

The guiding WeChat Subscription (Chuangyi) for traditional villages developed by the technological development center of the team includes the locations and basic information of more than 1200 islands in Zhoushan based on the Directory of Coastal Homestay Houses of Zhoushan Homestay House Association and gaining the coordinate position with Geocoding API of Baidu. It also has the functions of village introduction, homestay house information, uploading pictures, grading, lines, nearby conditions and other common functions. Now a new warning function is added so that users can contact corresponding departments and nearby teams through backstage notices when suffering emergencies in the coastal villages.

\section{2) Application program}

APP is the third program of intelligent mobile phones, which can be available to users directly on intelligent devices and provide related services to users. At present, multifarious APP products can meet users' various demands, and the users of intelligent mobile phones will take $60 \%$ of their time on new activities, including maps, games, social networking services and so on. APP software has permeated in trips, catering, shopping, medical treatment, financing, social contact and other fields of the life, so we believe it will influence all aspects of tourism more in the future.

For the development of coastal homestay houses, we shall establish APP platform and website of homestay houses to encourage more people to go to traditional coastal villages and experience the life in homestay houses, and then use the strength of users to collect the information of the homestay houses and traditional coastal villages in all various regions through users' high-quality comments, pictures, information supplement and other public collection methods in order to integrate the information of coastal villages in whole country and establish a national information sharing platform with homestay houses as main carriers.

\section{3) Positioning service}

LBS has two meanings: the first is to confirm the current geographic positions of users and relevant mobile devices; the second is to provide various information services near the positions, such as the positioning promotion for the new coastal homestay houses. LBS is divided into leisure and recreation type, life service type, social type and commerce type. We shall associate the services of LBS with the construction of coastal homestay houses more comprehensively with the continual consciousness improvement of the service quality of LBS and the privacy protection of users' positions.

\section{4) Sign-in pattern}

It means users sign in APP actively to share and record the locations synchronously with comments and records, and then high-quality contents can be produced. The biggest purpose of this pattern is to make users form the habit of signing in at every location. This business pattern is obvious, which can provide all kinds of marketing and popularization services to commercial tenants or brands and provide nearby life service search, life guideline, label sharing of tourism information and other functions.

\section{B. The Promotion Effect of Internet Plus on the Development of Coastal Homestay Houses}

The popularization and application of internet technology in the coastal homestay houses with original ecology includes two aspects: the first is to be a marketing method for homestay tourism; the second is to realize the protection and popularization of traditional coastal villages and ocean culture with homestay houses as carriers. The protection and activation of traditional coastal villages will deepen the economic stimuli produced by tourism development on the premise of protecting the traditional villages. We analyze the protection and development of traditional villages so as to analyze the change of tourism modes of with the change the public degree of participation under the influence of internet. "Table II"

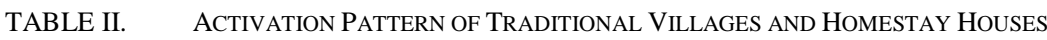

\begin{tabular}{|l|l|l|l|}
\hline $\begin{array}{c}\text { Five changes } \\
\text { Three degrees }\end{array}$ & \multicolumn{1}{|c|}{ Shallow } & \multicolumn{1}{|c|}{ Medium } & \multicolumn{1}{c|}{ Deep } \\
\hline Focalization & Vacationing and accommodation & $\begin{array}{l}\text { Activity experience and culture } \\
\text { creativity }\end{array}$ & $\begin{array}{l}\text { Vacationing and accommodation, and culture } \\
\text { creativity }\end{array}$ \\
\hline Diversification & $\begin{array}{l}\text { Vacationing and accommodation, homestay } \\
\text { events and festivals, and outdoor sports }\end{array}$ & $\begin{array}{l}\text { Activity experience, homestay events } \\
\text { and festivals, and outdoor sports }\end{array}$ & $\begin{array}{l}\text { Vacationing and accommodation, activity } \\
\text { experience, and homestay events and festivals }\end{array}$ \\
\hline Actualization & Homestay events and festivals & $\begin{array}{l}\text { Activity experience, homestay events } \\
\text { and festivals, and culture creativity }\end{array}$ & $\begin{array}{l}\text { Activity experience, homestay events and } \\
\text { festivals, and culture creativity }\end{array}$ \\
\hline Serialization & $\begin{array}{l}\text { Homestay events and festivals, and outdoor } \\
\text { sports }\end{array}$ & $\begin{array}{l}\text { Homestay events and festivals, outdoor } \\
\text { sports, and culture creativity }\end{array}$ & $\begin{array}{l}\text { Homestay events and festivals, and culture } \\
\text { creativity }\end{array}$ \\
\hline Annualization & $\begin{array}{l}\text { Vacationing and accommodation, and } \\
\text { homestay events and festivals }\end{array}$ & $\begin{array}{l}\text { Activity experience and homestay } \\
\text { events and festivals }\end{array}$ & $\begin{array}{l}\text { Vacationing and accommodation, activity } \\
\text { experience, and homestay events and festivals }\end{array}$ \\
\hline
\end{tabular}

The use of internet technology in this task will follow the following three principles: firstly, centered on the public, integrate the resources of homestay houses and establish a "virtual information center" of homestay houses, and then integrate of the technologies of tourism information, communication, online landscapes, calling center and others expect the homestay houses based on the public tourism demands. Secondly, on the basis of data, establish platforms integrated of homestay houses, scenic spot information, search of booking tickets and advertisement marketing between the tourism agency, cultural relics protection institution and other administrative and management organizations and the villages and scenic spots. Thirdly, systematically integrate the resources of homestay houses and deeply develop and use them, and 
establish a "virtual museum" with technology, such as cloud computing, mobile internet and data mining in order to realize the storage and popularization of traditional coastal villages, the resources of homestay houses and ocean culture with low cost and high return.

\section{COUNTERMEASURE RESEARCH OF ACTIVATION OF COASTAL VILLAGES AND HOMESTAY HOUSES IN ZHOUSHAN}

In the later popularization of rebuilding coastal homestay houses with original ecology, both marketing strategies and publicity means are the strong power to drive the later popularization of coastal homestay houses as long as we find out the relationship between them and connect them in series.

We shall seek the optimum effect of remoulding the original ecology in the multi-angle exploration process of the development of coastal homestay houses. Based on the discussion and research of the rebuilding and development of coastal homestay houses in Zhoushan and combined with relevant surveys and researches and concrete practice, we shall discuss the feasibility of protecting and activating coastal villages. The coastal homestay houses are still being developed. During this process, we shall always remember the idea that "green mountains and rivers are wealth" proposed by general secretary $\mathrm{Xi}$ and blend the idea of original ecology in the rebuilding of coastal homestay houses practically. The local government shall complete unified planning and management for the rebuilding of coastal homestay houses with corresponding policies to drive the ecological protection and activation of coastal homestay houses, and shall take fishermen as main body and appeal for all kinds of social support in order to realize the innovation and metamorphosis of coastal homestay houses. We hope to provide some reference value for rebuilding the coastal homestay houses with original ecology in Zhoushan through this article in order to realize the ecological protection and activation of coastal villages in Zhoushan in the background of internet Plus.

\section{CONCLUSION}

In the later popularization of rebuilding coastal homestay houses with original ecology, both marketing strategies and publicity means are the strong power to drive the later popularization of coastal homestay houses as long as we find out the relationship between them and connect them in series.

Based on the discussion and research of the rebuilding and development of coastal homestay houses in Zhoushan and combined with relevant surveys and researches and concrete practice, we shall discuss the feasibility of protecting and activating coastal villages. J Schittone (2001) discovered that the government preferred to intervene in the unfair competitive relationship between commercial fishing and tourism industry with monopoly groups when researching this relationship on Zhousi Island and Key West of Florida. However, on the contrary, it is advantageous to the sustainable development of island fishing villages with weak ecological environment system [7]. The coastal homestay houses are still being developed. During this process, we shall always remember the idea that "green mountains and rivers are wealth" proposed by general secretary $\mathrm{Xi}$ and blend the idea of original ecology in the rebuilding of coastal homestay houses practically. The local government shall complete unified planning and management for the rebuilding of coastal homestay houses with corresponding policies to drive the ecological protection and activation of coastal homestay houses, and shall take fishermen as main body and appeal for all kinds of social support in order to realize the innovation and metamorphosis of coastal homestay houses. We hope to provide some reference value for rebuilding the coastal homestay houses with original ecology in Zhoushan through this article in order to realize the ecological protection and activation of coastal villages in Zhoushan in the background of internet Plus.

\section{REFERENCES}

[1] Wu Wei, Research on Development Status and Digital Marketing Strategies of Homestay Houses in Taiwan, Wu [J], Journal of Quanzhou Normal University, 2015(3)

[2] Liu Lingling, Thinking on Developing Tourism of Beautiful Coastal Homestay Houses in Zhoushan [J], Rural Economy and Science, 2014:25(10)

[3] Zhoushan City Tourism Committee, 【 Government Records 】 It Is Feasible to Develop the Tourism of Beautiful Coastal Homestay Houses in Zhoushan [N], Zhoushan Daily, 2014-02-20

[4] Wang Yuewei, Research on Development Strategy of Ocean Tourism in Zhoushan City [D], Daliang Liaoning Normal University, 2006

[5] Li Ying, Analysis of Application and Safety of LBS [J], Neijiang Technology, 2012(10)

[6] Chen Qingning, Wang Peng, Practice of Internet Technology on Promoting the Protection and Tourism Development of Traditional Villages [J], Tourism Planning \& Design, 2015(17) 